\title{
Cineclube at School: Disseminating a Literary Culture from Actions of the ATLAS Project
}

\author{
Mirelly Éllen M. de Lucena ${ }^{1}$, Rodrigo A. Costa ${ }^{1}$, Jucelio S. dos Santos ${ }^{2}$ \\ ${ }^{1}$ Universidade Estadual da Paraíba (UEPB) \\ ${ }^{2}$ Universidade Federal de Campina Grande (UFCG) \\ lucenamirelly@gmail.com, rodrigo@ccea.uepb.edu.br, jucelio@copin.ufcg.edu.br
}

\begin{abstract}
We aim to detect the habitual expectations of students and teachers in the use of procedures that address the interest in reading and favor their practice. We present a description of the activities carried out in one of the schools attended during the implementation of the ATLAS project, located in the municipality of Catole do Rocha, where it was proposed the adoption of a ' $\mathrm{C} i$ neclube' in the teaching-learning process, aiming to provide a multidisciplinary vision that rescued student interest by practicing reading in a pleasant way. As a result, we observed that, we can encourage the participation of the student community in acquiring interest in the healthy habit of reading. We rescued the student's search for the library as a stimulating and supportive space for learning; We permeate the curiosity of reading by students to investigate available materials such as books, newspapers, comics and other available media.
\end{abstract}

\section{Introduction}

Methods that encourage reading and spreading of culture in school are quite discussed. The benefit promoted by these reflections is to provide theoretical and methodological support to help teachers carry out this task, in view of the challenge of capturing students' attention to reading in the face of innumerable forms of media and virtual interaction.

In high school, the activities are based on the systematization of concepts of literary and critical theory, in which it is necessary to reach greater depth, and reading is considered a means of study. Developing the habit of reading and using resources available in a library becomes a task of high reflection and practical procedures.. This requires the student to have a broad repertoire of readings, which promotes the individual's knowledge and ability to seek meaningful information [Martins 2006]. Therefore, it is necessary to produce innovative methods, so that the process of reading and culture, and consequently of writing, takes place pleasantly and dynamically.

We will present in this article the results obtained in the implementation of the 'Ação das Tecnologias na Aprendizagem Significativa' (ATLAS) project carried out at the Obdúlia Dantas school. We will report the experiences that the management team witnessed with the students and teachers of the mentioned school, mentioning the solutions found when applying a methodology of work different from what the school is accustomed to use. In our case, we implemented a movie theater with the purpose of bringing the student public the literary works available in the school library, starting from an initial contact with the works in a pleasant way, but that provided reflections and discussions around the teaching-learning process and reading practice. 
VIII Congresso Brasileiro de Informática na Educação (CBIE 2019)

Anais do XXV Workshop de Informática na Escola (WIE 2019)

\section{Methods}

The nature of the research of this paper is classified as a case study. The objective is to deepen knowledge about a problem that is not sufficiently defined, to stimulate its understanding, to suggest hypotheses and questions or to help develop theories that deal with this problem [Gil 2008]. In our case study, we tried to accustom students to the use of multimedia sources (video, e-book, films and documentaries) in the acquisition of culture.

Data collection was done through the prior application of questionnaires designed to diagnose students' interest in reading, and then by systematic observation of the interaction between teachers and students, as well as the development of didactic activities, after the activation of the movie club. The information gathered allowed a better understanding of the process of appropriation of technologies in the project execution.

\section{Background}

Reading is a source of knowledge that motivates the students to interact in various everyday situations and to think of information extracted from the surface of the text. The method of reading not only leads to a quality in the activity, but also means an acquisition of an instrument for the development of the reader's cultural life.

In spite of its relevance for the integral formation of the student, the formation of good readers presents a challenge. Forcing children and young people to read works they do not like may be the most effective way to bar their way and interest in reading [Magalhães and Alçada 1993]. On the other hand, compulsory reading of certain books at school may be the only opportunity for students have access to a more comprehensive reading. Thus, it is necessary to rethink the approach to reading in the classroom, keeping in mind that we need to consider what students need to become good readers and what teachers need to respond to those needs.

The formation of readers at different levels and instances can be made from three factors: i) the new possibilities in the field of reading and the opening of the process of reception and communication; ii) the mediator role of the teacher in the creation of new learning possibilities, and iii) the contribution of multimodality as a theory to support the productions and social practices of reading in development [Amarilha 2010].

The challenges with respect to reading in the virtual age means to understand the interactions between the act of reading (involves the culture) and the various forms of apprehension of reality (extrapolating traditional forms of reading) [Oliveira 2006]. In this new culture, also known as cyberculture, many children learn to manipulate the mouse and keyboard before they even learn to read and write. Contact with the digital world is facilitated by the school, social projects and access to lan houses. Thus, children and young people from different social strata today play video games and create their areas in social networks [Carneiro 2010]. Called by [Palfrey and Gasser 2011] of "digital natives", this generation comprises those born after 1980 and whose early contact with technology has direct consequences on world perception.

In fact, with the use of the Internet, not only there is greater contact with the written word, but greater possibilities of access to books, since it becomes possible to buy them and read them online, to know which library will have physical copies of a particular 
VIII Congresso Brasileiro de Informática na Educação (CBIE 2019)

Anais do XXV Workshop de Informática na Escola (WIE 2019)

work, or to ascertain the data of any volume, which before could be a very difficult task, or even impossible [Cassany and Allué 2012].

Due to media interactions, young people read more than before. First, because interactions through social networks or chats are also ways of reading. As far as the literature is concerned, the ease of access to books was also increased. However, it should be noted that the most successful literary genres nowadays are those associated with leisure rather than education: there is a preference for books that sharpen the imagination, especially those with witchcraft and vampire themes. The reading of classic literary works is still due to the pressure of the vestibular, which is not always accompanied by the expected effects on the comprehension of texts in general or the stimulus to 'pleasure' by the discovery of their possible meanings by the young reader [Gouveia 2010].

In order to stimulate reading amongst students, it is a necessity to pursue innovative dynamics and methodologies, which collaborate for an association between literature and leisure, contributing to the sensation of a pleasant and dynamic learning.

\section{ATLAS project}

Learning through sounds, images and media was one of the goals of the ATLAS project at Obdúlia Dantas school, where audiovisual resources were used to help students to read more naturally. The project encouraged students in this school to practice reading of classical works in workshops, films and documentaries of Brazilian, regional and local literary works, under a philosophy of daily reading practice, not only as a form of study, but as a source of pleasure and recreation. For that, there was use of the media such as radio, $\mathrm{TV}$, computers and Internet to streamline the actions of the project.

In this school, we opted for the creation of a film club ('Cineclube'), focusing on Brazilian and local productions, that functioned as a mechanism to approach transversal subjects in the classroom, while at the same time expanding the space for cultural leisure and enrichment of the school. The language of cinema is an important cultural production for the formation of the intellect of the people, because with it appears cognitive, artistic and affective issues of great significance [Pontuschka et al. 2009]. With the integration of the cinema into the school, the library's collection gained a new appeal: along with the multimedia resources, books began to have linked activities (videos, documentaries, movies, pedagogical tips and accessories) to be used in classes, in different subjects.

Our proposal to insert films in the teaching-learning process aimed at actions that stimulated multidisciplinary education that could bring the student public closer to the practice of reading in a pleasant perspective, contributing to the development of active and conscious citizens. The networked literary offers new possibilities of access, consultation of linguistic and cultural data, search for documentation, exchange of opinions between readers, amongst other resources [Cassany and Allué 2012].

\section{Results and discussions}

Considering the great challenge faced by teachers in increasing students' interest in reading, we proposed the creation of the 'Cineclube' at the Obdúlia Dantas school as a means of favoring spaces for literary reading in High School.

The activities of the 'Cineclube' were performed as per the following steps: i) we applied questionnaires to identify students' interest in reading; ii) we organized and 
VIII Congresso Brasileiro de Informática na Educação (CBIE 2019)

Anais do XXV Workshop de Informática na Escola (WIE 2019)

published a schedule of cinema sessions from the works indicated by the teachers, related to entrance exams and serial evaluations; iii) we held film-screening sessions with teachermediated debates. In these debates, we approached themes evoked by the works, which served to enrich the activities in class, interconnecting curricular contents of different disciplines to questions of the students' daily lifes.

As per students' answers in the questionnaires, applied before the activities of the film club began, we found that about $80 \%$ of the students had reading habits prior to our intervention, but infrequently: more than half of them read occasionally or rarely (Figure 1). Among the types of reading indicated, $42 \%$ were books and $35 \%$ were magazines.

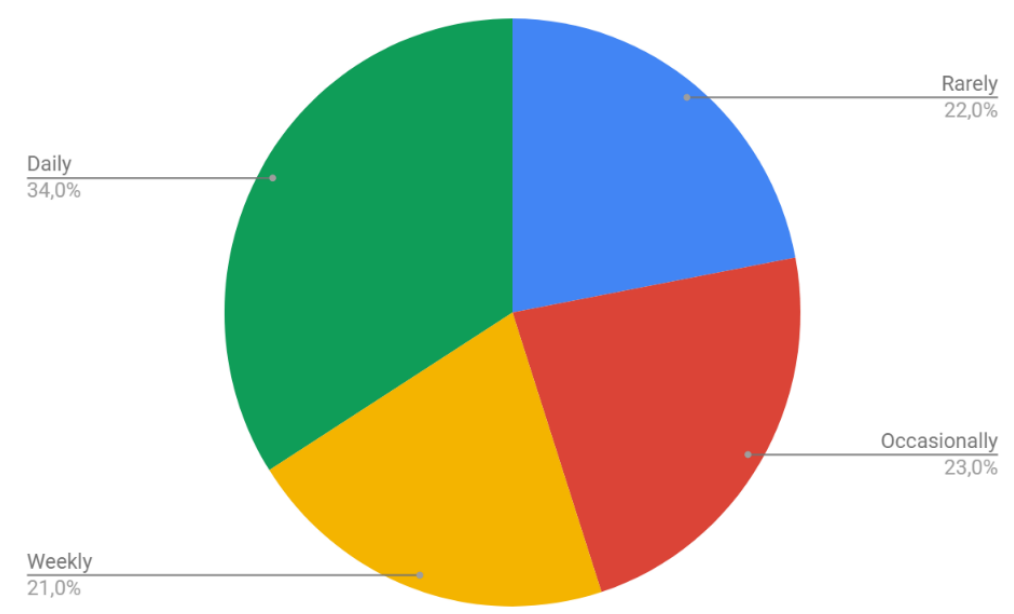

Figura 1. Frequency of reading of students of Obdúlia Dantas

Regarding the teacher's incentive to adopt steps to raise students' interest in reading, $57 \%$ of the interviewees stated that teachers used other means to stimulate the reading habit, such as video presentations and slides and music presentations.

With this information, our second step was to organize the 'Cineclube'. The school had a deactivated space called a 'multifunctional room' which we reactivated and where computers, a digital board, amplifier boxes, projectors and projection screens were installed, and thus the cinema was created. Then we organized and released a schedule of film sessions based on compulsory readings from the school, based on lists of entrance exams and the 'Exame Nacional de Ensino Médio' (ENEM). Sessions were held weekly, with one session reserved for each film, except for a few works that required additional action, as in the case of woodcuts 'Morte e vida severina' and from the short film of the classic "A ilha das flores".

From the film's presentation, we proposed an interdisciplinary activity with the Literature and Geography teachers. The 'severinos' (socially unprotected people) like those portrayed in the film were identified, but in their local reality. Thus, students would have to identify and characterize 'severinos' in poor communities of the municipality of Catolé do Rocha-PB and propose a concrete action of social and integrating character. Upon completion, students prepared a report on such reflections.

Another session of the project was associated with the short film 'Ilha das Flores', documentary written and directed by the filmmaker Jorge Furtado in 1989. The documen- 
VIII Congresso Brasileiro de Informática na Educação (CBIE 2019)

Anais do XXV Workshop de Informática na Escola (WIE 2019)

tary shows, by analogies, factors that influence misery. With a duration of 13 minutes, this short film can be easily embedded in class time, and emphasizes factors such as poverty, hunger and social exclusion, which have not changed much to this day.

After these interventions, we sought to investigate whether the project would have had an impact on the reading practice of the students. Data from the application of a new diagnostic questionnaire indicated a $7 \%$ increase in interest in reading and a habit of reading increased, since about $50 \%$ of the students started to consult the library daily through a reading follow-up record, $45 \%$ of students read more often.

\section{Conclusions}

The actions of the ATLAS project carried out at the Obdúlia Dantas school served to enhance and renew traditional practices, without necessarily replacing them. As a contribution to the implantation of our 'Cineclube': i) we can encourage the participation of the student community in acquiring interest in the healthy habit of reading. ii) we rescued the student's search for the library as a stimulating and supportive space for learning; iii) we permeate the curiosity of reading by students to investigate available materials such as books, newspapers, comics and other available media.

\section{Referências}

Amarilha, M. (2010). A formação do leitor no século xxi-a multimodalidade na formação do leitor contemporâneo. Reunião Anual da SBPC, 62.

Carneiro, J. D. (2010). Sem medo da tecnologia. Revista TV Escola, 2:27-33.

Cassany, D. and Allué, C. (2012). Leitura e literatura na era da internet. Revista Pátio, (15):6-9.

Gil, A. C. (2008). Métodos e técnicas de pesquisa social. Editora Atlas SA, 6 edition.

Gouveia, F. (2010). Leitura na era digital, volume 1. Pre-Univesp, São Paulo.

Magalhães, A. M. and Alçada, I. (1993). Os jovens e a leitura nas vésperas do século xxi. Cadernos.Lisboa: Caminho.

Martins, I. (2006). A literatura no ensino médio: quais os desafios do professor. Português no ensino médio e formação do professor. São Paulo: Parábola Editorial, pages 83102.

Oliveira, D. L. (2006). Leitura e cibercultura: navegando em oceanos pedagógicos ou por uma educação popular nunca de antes navegada. $\mathrm{PhD}$ thesis, Tese de doutorado em Educação - Curso de Pós-graduação em Educação, Universidade Federal da Paraíba.

Palfrey, J. and Gasser, U. (2011). Nascidos na era digital: entendendo a primeira geração de nativos digitais. Porto Alegre: Editora Artmed, 1 edition.

Pontuschka, N. N., Paganelli, T. I., and Cacete, N. H. (2009). Para ensinar e aprender Geografia. São Paulo: Cortez., 3 edition. 